\title{
Aplikasi Pengukuran Tingkat Kecemasan Berdasarkan Skala Hars Berbasis Android
}

\author{
Giatika Chrisnawati $^{1}$, Tutuk Aldino ${ }^{2}$ \\ ${ }^{1}$ Universitas Bina Sarana Informatika \\ e-mail: giatika.gcw@bsi.ac.id \\ ${ }^{2}$ STMIK Nusa Mandiri Jakarta \\ e-mail: tutukaldino1@gmail.com
}

\begin{abstract}
The development of technology that getting increasingly has an impact on a mobile device. In this era, mobile phone is a communication tool that is flexible, easy to carry anywhere, and its function is almost the same as the computer. The operating system that mobile phone has got increasingly. One of them is that Android operating system has grown rapidly and almost dominates the mobile market. The development of technology and the increase of necessities life make people have to work harder to sufficient their life. People compete to sufficient the needs and keep up the development that exists, but not everyone is able to sufficient it. It makes people want to do crimes like theft, corruption, murder, etc. This happens because someone is too obsessed with their desire. so they are afraid and anxious if they cannot sufficient and achieve their desire. Anxiety can be interpreted as an uncertain fear with a feeling of uncertainty and helplessness that can cause an uncomfortable feeling. So, it triggers their self to do bad things. In this phenomenon is needed an application that can be used to determine the level of anxiety because knowing the level of anxiety early can prevent people to do bad things. The measurement applications of anxiety levels with HARS scale are made based on the Hamilton Anxiety Rating Scale (HARS).
\end{abstract}

Keywords: HARS, Anxious, Android

\section{PENDAHULUAN}

Di era globalisasi yang terus berkembang ini membuat kebanyakan orang merasa cemas untuk memenuhi kebutuhan. Rasa cemas tidak hanya dialami oleh orang tua atau dewasa saja, melainkan anak sekolah, remaja bahkan lansia. Di Indonesia prevalensi terkait gangguan kecemasan menurut hasil Riset Kesehatan Dasar (Riskesdas) pada tahun 2013 menunnjukan bahwa sebesar 6\% untuk usia 15 tahun ke atas atau sekitar 14 juta penduduk di Indonesia mengalami gangguan mental emosional yang ditunjukan dengan gejala kecemasan dan depresi (KEMENKES, 2014). Kecemasan pada ilmu kedokteran sering dikenal dengan nama anxietas. Anxietas dapat ditimbulkan dari situasi atau obyek tertentu bahkan bisa timbul dari individu itu sendiri, seperti perasaan takut akan sesuatu yang akan dihadapinya.

Beberapa skala penelitian dikembangkan untuk melihat seberapa besar tingkat kecemasan seseorang, salah satunya yaitu Hamilton Anxiety Rating Scale (HARS). HARS menggunakan serangkaian pertanyaan dengan jawaban yang harus diisi oleh pasien sesuai dengan kondisi yang dirasakan oleh pasien tersebut. Jawaban yang diberikan merupakan skala (angka) 0, 1, 2, 3, atau 4 yang menunjukan tingkat gangguan dan setelah pasien menjawab sesuai apa yang dirasakanya, maka hasilnya dapat dihitung dengan menjumlahkan total skor yang didapat dari setiap soal (pernyataan).

Menurut (Kautsar, Gustopo, \& Achmadi, 2015) telah menyimpulkan "Pengujian validitas dan reliabilitas yang dilakukan pada instrumen HARS menunjukan bahwa instrumen tersebut mampu mengungkap tingkat kecemasan terhadap produktivitas pegawai serta konsistensi responden dalam mengisi instrumen dapat diandalkan. Validitas instrumen HARS ditunjukan pada bagian Corrected Item-Total Correlation seluruh soal memiliki nilai positif dan lebih besar dari syarat 0.05 , sedangkan reliabilitas ditunjukan dengan nilai Cronbach's Alpha adalah 0.793 dengan jumlah item 14 butir lebih besar dari 0.6, maka kuisoner yang digunakan terbukti reliabel (0.793\&gt;0.6). Sehingga HARS dianjurkan untuk mengukur tingkat kecemasan terhadap produktivitas pekerja."

Agar gangguan kecemasan dapat dideteksi sedini mungkin dan untuk membantu tenaga kesehatan mengukur tingkat kecemasan pasiennya, atau bahkan masyarakat umum yang tidak memiliki materi dan waktu untuk melakukan tes kecemasan maka dibutuhkan pemanfaatan teknologi android 
berupa Aplikasi Pengukuran Tingkat Kecemasan Berdasarkan Skala HARS

\section{METODOLOGI PENELITIAN}

\section{Pengertian Kecemasan}

Menurut (Gunarso, n.d, 2008) "Kecemasan atau anxietas adalah rasa khawatir, takut yang tidak jelas sebabnya. Pengaruh kecemasan terhadap tercapainya kedewasaan, merupakan masalah penting dalam perkembangan kepribadian. Kecemasan merupakan kekuatan yang besar dalam menggerakan. Baik tingkah laku normal maupun tingkah laku yang menyimpang, yang terganggu, kedua-duanya merupakan pernyataan, penampilan, penjelmaan dari pertahanan terhadap kecemasan itu. Jelaslah bahwa pada gangguan emosi dan gangguan tingkahlaku, kecemasan merupakan masalah pelik."

$$
\text { Apakah semua orang mengalami }
$$

kecemasan? Tidak seorangpun bebas dari kecemasan. Semua orang pasti merasakan kecemasan dalam derajat tertentu. Bahkan kecemasan yang ringan dapat berguna yakni dalam memberikan rangsangan terhadap seseorang. Rangsangan untuk mengatasi kecemasan dan membuang sumber kecemasan. Kecemasan yang membuat orang putus asa dan tidak berdaya sehingga mempengaruhi seluruh kepribadiannya adalah kecemasan yang negatif. Rasa takut ditimbulkan oleh adanya ancaman, sehingga seseorang akan menghindar diri dan sebagainya.

Kecemasan atau anxietas dapat
ditimbulkan

oleh bahaya dari luar, mungkin juga oleh bahaya dari dalam diri seseorang, dan pada umumnya ancaman itu samar-samar. Bahaya dari dalam, timbul bila ada sesuatu hal yang tidak dapat diterimanya, misalnya pikiran, perasaan, keinginan, dan dorongan.

\section{Tingkat-Tingkat Kecemasan}

Menurut Pasaribu dalam (Ramadhan, 2017) "Kecemasan ada empat tingkatan dengan penjelasan dan efeknya sebagai berikut:

a. Ansietas Ringan

Ansietas ringan terjadi saat ketegangan hidup sehari-hari. Selama tahap ini seseorang waspada dan lapangan persepsi meningkat. Kemampuan seseorang untuk melihat, mendengar, dan menangkap lebih dari sebelumnya. Jenis ansietas ringan dapat memotivasi belajar dan menghasilkan pertumbuhan dan kreatifitas.

b. Ansietas Sedang

Ansietas sedang dimana seseorang hanya berfokus pada hal yang penting saja lapang persepsi menyempit sehingga kurang melihat, mendengar, dan menangkap. Seseorang memblokir area tertentu tetapi masih mampu mengikuti perintah jika diarahkan untuk melakukannya.

c. Ansietas Berat

Ansietas berat ditandai dengan penurunan yang signifikan di lapang persepsi. Cenderung memfokuskan pada hal yang detail dan tidak berfikir tentang hal lain. Semua perilaku ditunjukan untuk mengurangi ansietas, dan banyak arahan yang dibutuhkan untuk fokus pada area lain

d. Panik

Dikaitkan dengan rasa takut dan teror, sebagian orang yang mengalami kepanikan tidak dapat melakukan hal-hal bahkan dengan arahan. Gejala

panik adalah peningkatan aktivitas motorik, penurunan kemampuan untuk berhubungan dengan orang lain, persepsi yang menyempit, dan

kehilangan pemikiran rasional. Orang panik tidak mampu berkomunikasi atau berfungsi secara efektif. Kondisi panik yang berkepanjangan akan

menghasilkan kelelahan dan kematian. Tapi panik dapat diobati dengan aman dan efektif."

\section{Hamilton Anxiety Rating Scale (HARS)}

Menurut (Saputro \& Fazris, 2017)

"Hamilton Anxiety Rating Scale (HARS), pertama kali dikembangkan oleh Max Hamilton pada tahun 1956, untuk mengukur semua tanda kecemasan baik psikis maupun somatik. HARS terdiri dari 14 item pertanyaan untuk mengukur tanda adanya kecemasan pada anak dan orang dewasa."

Skala HARS penilaian kecemasan terdiri dari 14 item, meliputi:

a. Perasaan Cemas, firasat buruk, takut akan pikiran sendiri, mudah tersinggung.

b. Ketegangan: merasa tegang, gelisah, gemetar, mudah menangis, dan lesu, tidak bisa istirahat tenang, dan mudah terkejut.

c. Ketakutan: takut terhadap gelap, terhadap orang asing, bila ditinggal sendiri, pada binatang besar, pada keramain lalu lintas, dan pada kerumunan orang banyak.

d. Gangguan tidur: sukar memulai tidur, terbangun pada malam hari, tidur tidak pulas, bangun dengan lesu, banyak mimpi-mimpi, mimpi buruk, dan mimpi menakutkan.

e. Gangguan kecerdasan: daya ingat buruk, susah berkonsentrasi.

f. Perasaan depresi: hilangnya minat, berkurangnya kesenangan pada hobi, sedih, bangun dini hari, perasaan berubah-ubah sepanjang hari.

g. Gejala somatik: sakit dan nyeri otot, kaku, kedutan otot, gigi gemerutuk, suara tidak stabil.

h. Gejala sensorik: tinitus, penglihatan kabur, muka merah atau pucat, merasa lemas, dan perasaan ditusuk-tusuk.

i. Gejala kardiovaskuler: berdebar, nyeri di dada, denyut nadi mengeras, perasaan lesu lemas seperti mau pingsan, dan detak jantung hilang sekejap.

j. Gejala pernapasan: rasa tertekan di dada, perasaan tercekik, sering menarik napas, napas pendek/ sesak. 
k. Gejala gastrointestinal: sulit menelan, perut melilit, gangguan pencernaan, nyeri sebelum dan sesudah makan, perasaan terbakar di perut, kembung, mual, muntah, buang air besar lembek, berat badan turun, susah buang air besar.

1. Gejala urogenital : sering kencing, tidak dapat menahan air seni, amenorrhoe, menorrhagia, frigid, ejakulasi praecocks, ereksi lemah, dan impotensi.

m. Gejala otonom: mulut kering, muka merah, mudah berkeringat, pusing, dan bulu roma berdiri.

n. Perilaku sewaktu wawancara: gelisah, tidak tenang, jari gemetar, kerut kening, muka tegang, tonus otot meningkat, napas pendek cepat, dan muka merah.

Cara penilaian kecemasan adalah dengan memberikan nilai dengan kategori:

$0=$ tidak ada gejala sama sekali

$1=$ satu gejala yang ada

$2=$ sedang/separuh gejala yang ada

$3=$ berat/ lebih dari separuh gejala yang ada

$4=$ sangat berat semua gejala ada

Penentuan derajat kecemasan dengan cara menjumlahkan skor 1-14 dengan

hasil:

Skor kurang dari 14 = tidak ada kecemasan

Skor $14-20=$ kecemasan ringan

Skor 21-27 = kecemasan sedang

Skor 28-41 = kecemasan berat

Skor $42-52=$ kecemasaan berat sekali

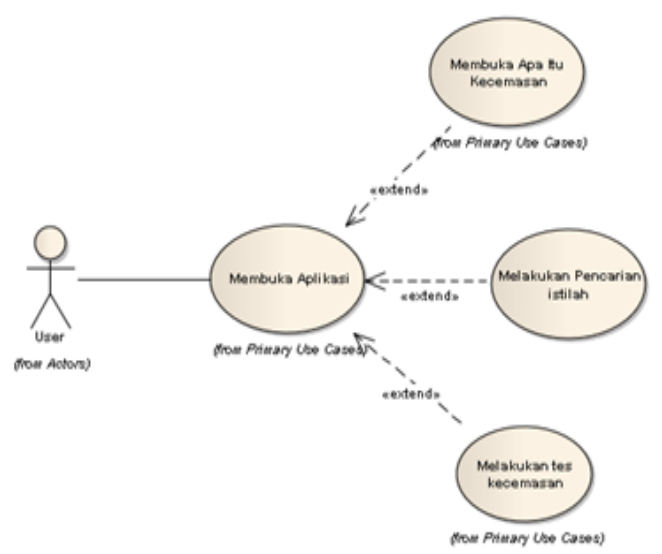

\section{HASIL DAN PEMBAHASAN}

Berikut ini adalah hasil rancangan aplikasi pengukuran tingkat kecemasan berdasarkan skala hars berbasis android

\section{Use Case Diagram}

Gambar 1. Use Case Diagram Aplikasi
Tabel 1. Deskripsi Use Case Aplikasi

\begin{tabular}{cc}
\hline Use & Deskripsi \\
\hline $\begin{array}{c}\text { Brief } \\
\text { Description }\end{array}$ & $\begin{array}{c}\text { Use Case ini memungkinkan User } \\
\text { untuk dapat memilih Menu }\end{array}$ \\
\hline Actor & Pengguna \\
\hline Precondition & $\begin{array}{c}\text { User memilih menu apa itu } \\
\text { kecemasan, pencarian istilah, atau tes } \\
\text { kecemasan yang telah tersedia }\end{array}$ \\
\hline Main flow & $\begin{array}{c}\text { Use case ini dimulai pada saat } \text { user } \\
\text { mengklik salah satu dari pilihan } \\
\text { Menu }\end{array}$ \\
\hline Alternatif Flow & $\begin{array}{c}\text { Jika } \text { User tidak memilih pilihan } \\
\text { Menu } \text { maka } \text { User dapat mengklik } \\
\text { tombol kembali }\end{array}$ \\
\hline Postcondition & $\begin{array}{c}\text { Setelah } \text { User berhasil melihat pilihan } \\
\text { Menu, User } \text { dapat langsung memilih } \\
\text { Menu }\end{array}$ \\
\hline
\end{tabular}

\section{Activity Diagram}

a. Activity Diagram Apa Itu Kecemasan

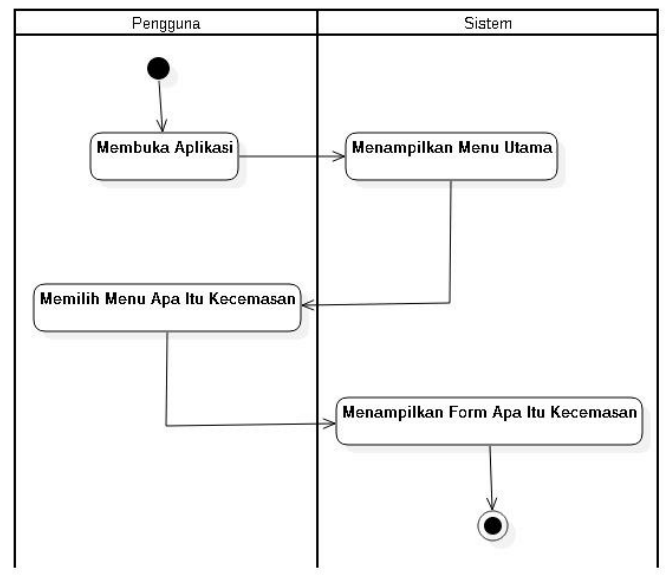

Gambar 2. Activity Diagram Apa Itu Kecemasan 
Gambar 4. Activity Diagram Tes Kecemasan

b. Acivity Diagram Istilah-istilah Penting

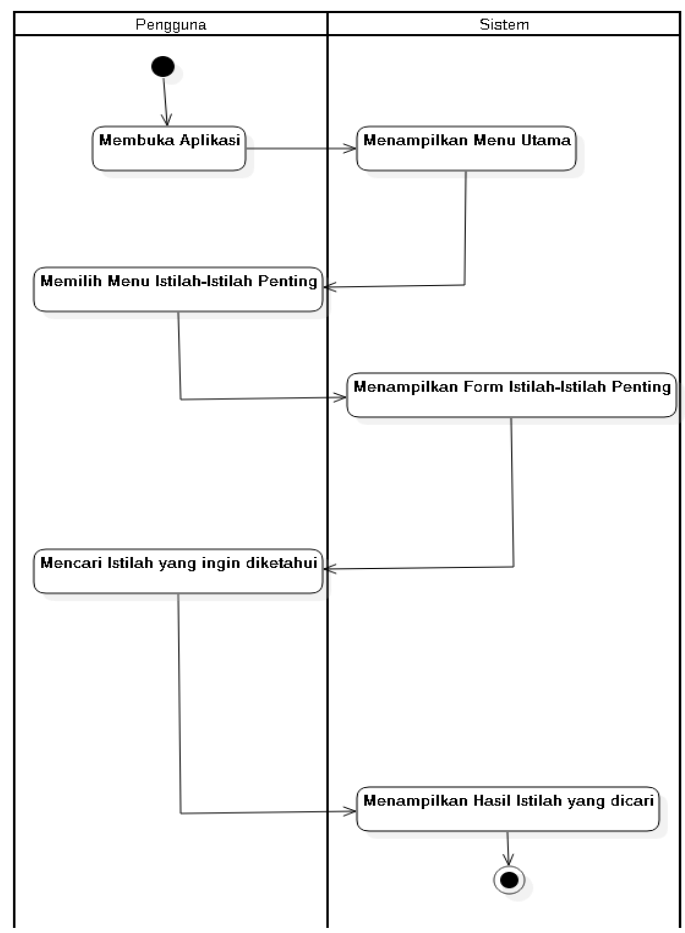

\section{Implementasi}

Implementasi dari aplikasi mobile ini terdiri dari beberapa halaman yang memiliki fungsi masing-masing. Halaman tersebut akan tampil setelah pengguna melakukan perintah tertentu. Implementasi antarmuka berikut ini diambil langsung dari implementasi pemasangan aplikasi mobile pada smartphone berbasis android.

a. Halaman Menu Utama

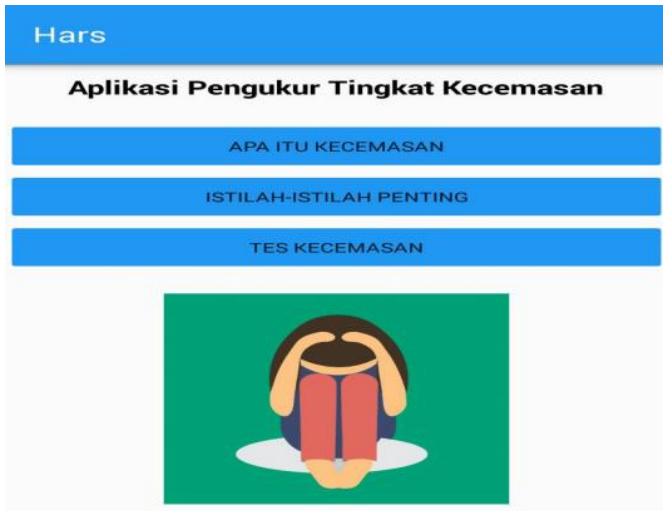

\section{$<$}

Gambar 5. Tampilan Menu Utama

b. Halaman Menu Apa Itu Kecemasan

Kecemasan Adalah

\section{Apa Itu \\ Kecemasan}

Kecemasan pada ilmu kedokteran sering dikenal

dengan nama anxietas.

Kecemasan sendiri dapat

ditimbulkan dari situasi atau

objek tertentu bahkan bisa

timbul dari diri kalian sendiri.

Anxietas dapat diartikan rasa

takut yang tidak jelas dan

disertai dengan perasaan

ketidakpastian,

ketidakberdayaan, isolasi, dan

$<$

Gambar 6. Tampilan Menu Apa Itu Kecemasan 


\section{c. Halaman Menu Istilah-Istilah Penting}

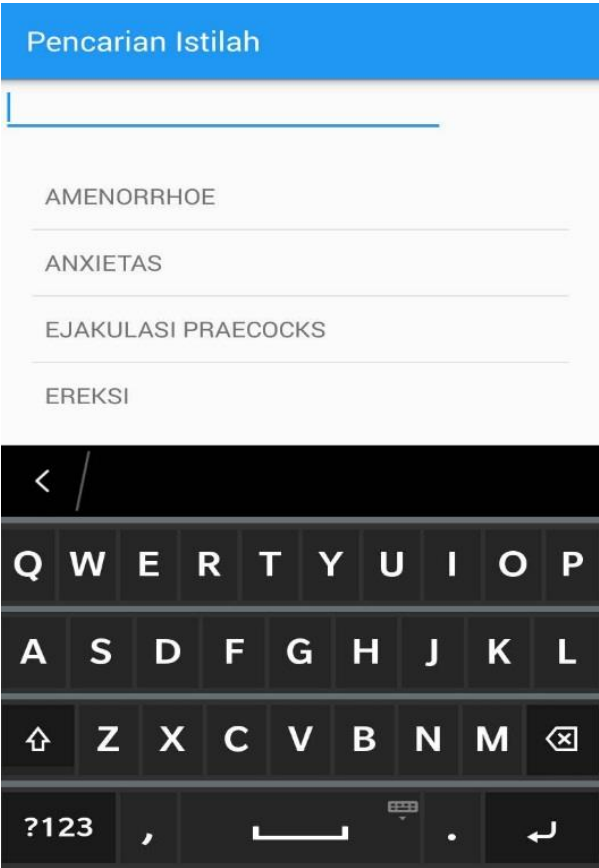

Gambar 7. Tampilan Menu Istilah Penting

d. Halaman Menu Tes Kecemasan

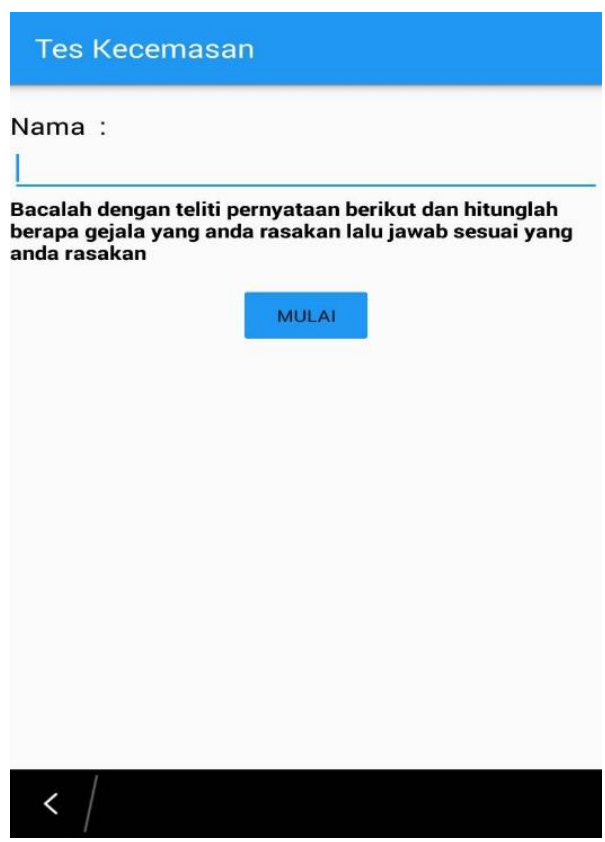

Gambar 8.Tampilan Menu Tes Kecemasan sebelum input nama pengguna

\section{Tes Kecemasan}

Nama :

Unggul

Bacalah dengan teliti pernyataan berikut dan hitunglah berapa gejala yang anda rasakan lalu jawab sesuai yang anda rasakan

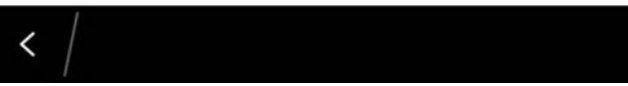

Gambar 9.Tampilan Menu Tes Kecemasan setelah input nama pengguna

\section{No 1}

Silahkan baca dengan teliti pernyataan berikut dan jawablah berapa gejala yang anda rasakan.

Perasaan Ansietas

a.Cemas

b.Firasat Buruk

c. Takut Akan Pikiran Sendiri

d.Mudah Tersinggung

o(tidak ada gejala)

(2) 1 (satu gejala)

2(dua gejala)

3(tiga gejala)

LANJUT

4(empat gejala)

\section{$<$}

Gambar 10. Tampilan Menu Tes Kecemasan pada soal atau pernyataan pertama 


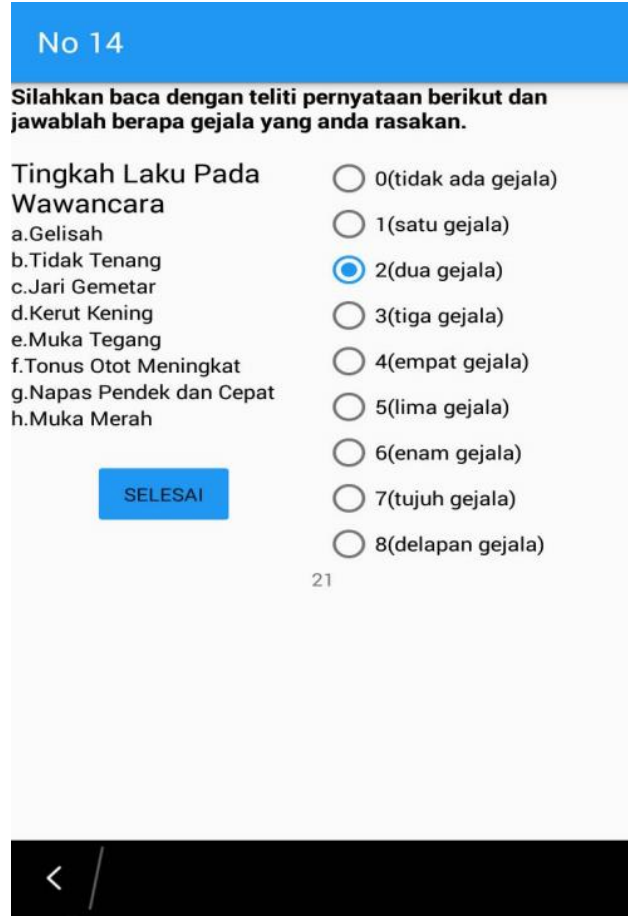

Gambar 11. Tampilan Menu Tes Kecemasan pada soal atau pernyataan terkakhir

\begin{tabular}{|c|c|}
\hline $\begin{array}{l}\text { Nama } \\
\text { Skor } \\
\text { Tingkat Kecemasan }\end{array}$ & $\begin{array}{l}\text { Unggul } \\
22 \\
\text { Kecemasan Sedang }\end{array}$ \\
\hline & LESAI \\
\hline
\end{tabular}

\section{$<$}

Gambar 12. Tampilan Hasil Proses Tes Kecemasan

\section{KESIMPULAN}

Berdasarkan permasalahan yang telah dibahas dan diselesaikan melalui Aplikasi Pengukuran Tingkat Kecemasan Berdasarkan Skala Hars Berbasis Android", maka dapat di ambil beberapa kesimpulan yaitu:

1. Dengan adanya aplikasi ini dapat mempermudah pengguna untuk melakukan pengukuran tingkat kecemasan yang sedang dialami.

2. Aplikasi ini dapat digunakan sebagai media informasi tentang risiko-risiko atau dampak dari kecemasan.

\section{REFERENSI}

Gunarso, S. D. (n.d.). d08120110-150-gun-ppsikologi-perawatan_library-stikespekajangan-2014.pdf.

Kautsar, F., Gustopo, D., \& Achmadi, F. (2015). Uji Validitas dan Reliabilitas Hamilton Anxiety Rating Scale Terhadap Kecemasan dan Produktivitas Pekerja Visual Inspection PT. Widatra Bhakti. 588-592.

KEMENKES, I. (2014). Stop Stigma dan Diskriminasi Terhadap Orang dengan Gangguan Jiwa (ODGJ). Kementrian Kesehatan Republik Indonesia, (18), 1.

Ramadhan, A. F. (2017). Perbedaan Derajat Kecemasan Antara Mahasiswa Tahap Akademik Tingkat Awal Dengan Tingkat Akhir Di Fakultas Kedokteran Universitas Lamppung. 1-49.

Saputro, H., \& Fazris, I. (2017). Anak Sakit Wajib Bermain di Rumah Sakit.

\section{PROFIL PENULIS}

1. Giatika Chrisnawati Lahir di Jakarta 6 Feruari 1982, bekerja sebagai Dosen pada Program Studi Teknologi Komputer Universitas Bina Sarana Informatika.

2. Tutuk Aldino, Lahir di Semarang 20 Agustus 1996, memperoleh gelar Sarjana Komputer dari STMIK Nusa Mandiri. 